\title{
Wetland Functional Responses to Prolonged Inundation in the Active Mississippi River Floodplain
}

\author{
Jaybus J. Price $^{1}$ - Jacob F. Berkowitz ${ }^{1}$ (1)
}

Received: 1 March 2020 / Accepted: 6 May 2020 / Published online: 27 June 2020

(C) The Author(s) 2020

\begin{abstract}
The Mississippi River experienced historic flooding during 2019, inducing $>150$ days of floodplain wetland inundation. We evaluated flood effects using repeated measures of hydrogeomorphic (HGM) wetland assessment variables prior to the flood (October 2018), immediately post-flood (August 2019) and one year after initial assessment (October 2019). The flood had little/ no impact on 11 of 13 assessment variables, but altered the abundance of woody debris and forest floor litter. Immediately after the flood, these changes decreased the functional capacity of wetlands to 1) detain floodwater (mean $-9.7 \%$ reduction) and 2) precipitation $(-17.3 \%)$; 3 ) cycle nutrients $(-7.5 \%)$; and export organic carbon $(-23.8 \%)$. Subsequent sampling documented the detain precipitation function returning to pre-flood conditions. The export organic carbon function also improved, yet remained below pre-flood levels. Other functions will likely require additional recovery time due to the persistence of accumulated excess woody debris. Across all sample intervals, floodplain wetlands displayed high wetland function capacities and appear resilient to surface water inundation. This analysis highlights the utility of the HGM assessment to detect responses to changing environmental conditions over short time intervals. The study also emphasizes the need to incorporate metrics with appropriate impactresponse characteristics when developing and implementing ecological assessments.
\end{abstract}

Keywords Mississippi River $\cdot$ Wetland function $\cdot$ Forested wetland $\cdot$ Hydrogeomorphic $(H G M)$ assessment $\cdot$ Floodplain

\section{Introduction}

The Mississippi River watershed conveys water from $41 \%$ of the conterminous United States, representing the world's fourth largest river system. The lower portion of the Mississippi River valley historically supported 10 million ha of floodplain forested wetlands, far exceeding the spatial extent of other large wetland systems including the Everglades, Okeefenokee, and Great Dismal swamps (Turner et al. 1981; The Nature Conservancy 1992). Forested wetlands in the Mississippi River valley provide a wide variety of ecological functions related to hydrology, habitat, and biogeochemical cycling that in turn benefit society through regulation of flooding, provide economic and recreational value, and improve water quality (Smith and Klimas 2002). Landscape scale alterations in the region resulted in an estimated $70 \%$

Jacob F. Berkowitz

Jacob.F.Berkowitz@usace.army.mil

1 US Army Engineer Research and Development Center, Vicksburg, MS, USA reduction in forested wetland extent, mostly associated with conversion to agricultural lands, drainage for development, and the construction of flood control infrastructure (Stanturf et al. 2000).

In particular, the establishment of more than $3500 \mathrm{~km}$ of levees adjacent to the main channel of the Mississippi River provides for navigation, agriculture, and economic development; protects over 4 million people from flooding; and has prevented over one trillion dollars in flood damage since its inception (Camillo 2012). The levee system also induced dramatic ecological changes (DuBowy 2013), decreasing the active Mississippi River floodplain area by $75-90 \%$ which altered the timing and extent of floodplain inundation (Schramm et al. 2015; Remo et al. 2018). The constriction of the river to a narrow floodplain results in more erratic flow regimes, more frequent major floods, and fewer years with stable water levels (Sparks et al. 1998). These altered flood regimes have important implications for faunal populations, vegetation communities and soil characteristics (Jones et al. 2019). For example, De Jager et al. (2012) reported a decrease in plant diversity and increases in fine soil textures with longer flood durations in the Mississippi River valley. Schramm et al. 
(2009) modeled nutrient cycling changes in the region under present day and historic hydroperiods, with results suggesting that the present inundation cycle removes less nitrogen than historic conditions. Despite the size and importance of the Mississippi River system, few studies investigate the implications of altered flood pulses on wetland functions and more research is required to evaluate the impacts of long duration, major flood events in large floodplain wetlands.

The Mississippi River watershed experienced historic flooding during 2019, including periods exceeding 150 days above flood stage in many areas (Fig. 1; Table 1), and resulting in an estimated $\$ 20$ billion dollars in economic losses (NOAA 2020). The unusual duration of flooding provided an opportunity to evaluate changes in wetland functions following an extreme sustained flood event, including short term recovery potential following floodwater recession. In response, we applied the hydrogeomorphic (HGM) wetland functional assessment approach prior to the onset of 2019 flooding (October 2018) and at two sampling intervals following floodwater recession (August 2019 and October 2019). The objectives of the study included 1) determine if the HGM approach detected flood effects and identify associated assessment variables, 2) document implications for wetland functions, and 3) evaluate potential functional recovery during short $(<1$ year) time frames.

\section{Methods}

The HGM wetland functional assessment developed by Murray and Klimas (2013) was applied at 35 locations within the active floodplain (i.e., batture) of the mainline Mississippi river levee system. The analysis included study sites in Missouri, Arkansas, and Tennessee. Sample locations all occurred within the low-gradient riverine overbank wetland subclass and exhibited hydric soils, mature forests dominated by hyrdrophytic vegetation, and indicators of wetland hydrology (USACE 2010). Common soils within the study area included Sharkey (Very-fine, smectitic, thermic Chromic Epiaquert), Robinsonville (Coarse-loamy, mixed, superactive, nonacid, thermic Typic Udifluvents), Commerce (Fine-silty, mixed, superactive, nonacid, thermic Fluvaquentic Endoaquepts), and associated series. Generally, Celtis laevigata, Salix nigra, Fraxinus pennsylvanica, and Populus deltoides dominated the tree stratum; Forestiera acuminata and Cephalanthus occidentalis were common shrub species; Saururus cernuus and Toxicodendron radicans were frequently observed herbaceous plants. Multiple indicators of wetland hydrology were present at each sample location, examples include: Surface Water, High Water Table, Saturation, Sediment Deposits, Drift Deposits, Water Marks, Surface Soil Cracks, Drainage Patterns, Moss Trim Lines, Geomorphic Position, and Crawfish Burrows (USACE 2010).
Sample locations were selected based upon their proximity to proposed levee improvement projects, the presence of forested floodplain wetlands, and existing right of entry agreements that provided for site access to conduct the wetland assessment. Data collection occurred at the same study locations at three intervals: prior to the flood in October 2018 (i.e., pre-flood); $<30$ days following the recession of floodwaters in August 2019 (post-flood1); and one year after initial data collection in October 2019 (post-flood2). A combination of 13 onsite and offsite variables were collected at each location during each sampling interval (Table 2). Variable metric data was transformed into variable subindex scores ranging from 0.0 to 1.0 , and wetland functional capacity index (FCI) scores were calculated using empirical equations (Table 3 ).

Statistical analysis compared assessment variable metrics, variable subindex scores and wetland functional capacity indexes at the three sampling intervals using a repeated measures approach in SPSS version 26.0 (IBM, Inc). The nonparametric Freidman's test was applied $(\alpha<0.05)$ because the data displayed marked deviations from normal distributions. Where differences were detected, post-hoc testing using Wilcoxon signed-rank test with Bonferroni-adjustment $(\alpha<$ 0.017 ) identified differences between sample intervals (preflood vs. post-flood1; pre-flood vs. post-flood2; post-flood1 vs. post-flood2).

\section{Results}

Eleven of the $13 \mathrm{HGM}$ wetland assessment variables displayed limited/no differences between sampling intervals, including all of the off-site variables (e.g., tract size, habitat connectivity) and a subset of the on-site variables (e.g., tree species composition). For example, the tree basal area fluctuated slightly between the pre-flood (mean \pm standard error $=$ $15.7 \pm 0.75)$, post-flood1 (14.8 \pm 0.74$)$, and post-flood2 (14.8 $\pm 0.63)$ sampling intervals but the changes were minor $(\mathrm{p}=$ 0.912). Areas subject to micro-depressional ponding also showed little change (pre-flood $=35.3 \pm 3.5 \%$; post-flood $1=$ $39.7 \pm 3.7 \%$; post-flood $2=35.4 \pm 2.5 \% ; \mathrm{p}=0.575$ ).

Alternatively, the downed woody debris and snags variable exhibited an increase following the flood, with higher than normal abundance of woody materials present at $40 \%$ of study locations and excessive amounts (> 25\% of ground coverage) of downed wood at 2 of the 35 locations evaluated during both post-flood sampling intervals $(p<0.001)$. The changes in observations of woody debris persisted between the post-flood 1 and post-flood2 sample intervals $(p=1.0)$. The leaf litter cover variable also displayed differences following flooding. Prior to the flood, litter covered $92.6 \pm 2.3 \%$ of the forest floor, flooding decreased surface litter cover to $22.8 \pm 4.1 \%$ during the post-flood 1 sampling interval $(\mathrm{p}<0.001)$. The 


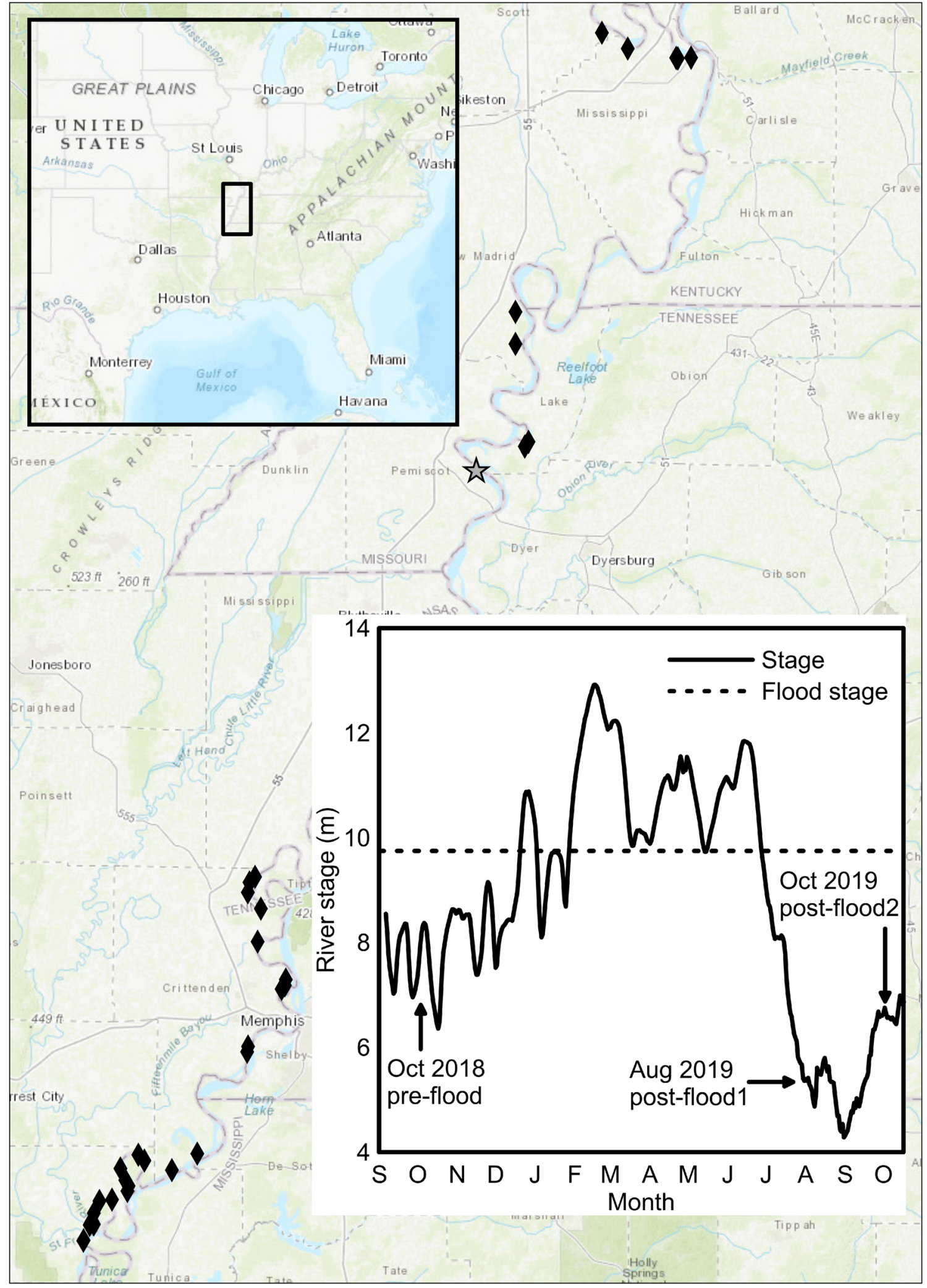

Fig. 1 Study locations ( $\downarrow$ ) within the active Mississippi River floodplain and hydrograph of the 2018-2019 period indicating the timing of repeated wetland functional assessments. Mississippi River stage data from the Caruthersville, MO gauge $(\star)$

litter cover subsequently rebounded to $68.4 \pm 3.9 \%$ over the next 90 days (post-flood2), higher than post-flood1 (p
$<0.001)$ but remained depressed compared to pre-flood conditions $(\mathrm{p}<0.001)$. 
Table 1 Duration and maximum height of recent major Mississippi River flood events at Caruthersville, MO

\begin{tabular}{lll}
\hline Year & Flood duration (days exceeding flood stage) & Maximum flood stage (m) \\
\hline 1973 & 111 & 12.9 \\
1979 & 71 & 12.7 \\
1983 & 73 & 12.6 \\
1993 & 86 & 11.1 \\
2008 & 104 & 15.1 \\
2011 & 84 & 14.5 \\
2017 & 23 & 12.0 \\
2019 & 162 & 12.9 \\
\hline
\end{tabular}

As expected based on the variable metric results, wetland assessment variable subindex values followed similar trends with limited/no differences detected in 11 of the 13 parameters (Fig. 2). The $\mathrm{V}_{\text {DWD\&S }}$ variable displayed a change following flooding $(\mathrm{p}<0.001)$, that persisted between post-flood sampling intervals $(p=1.0)$. The $\mathrm{V}_{\text {LITTER }}$ variable exhibited a subsequent decrease $(p<0.001)$ followed by partial recovery $(\mathrm{p}<0.001)$.

The wetlands within the active floodplain exhibited high levels level of function, with average functional assessment scores of $0.93 \pm 0.02$ prior to the flood (Fig. 3). The high scores included functions related to hydrology (e.g., detain floodwater and precipitation), biogeochemical cycling (i.e., export organic carbon, cycle nutrients), and habitat for plants and animals. The variable responses induced by flooding resulted in decreases in four of the six wetland functional capacities examined. The detain floodwater (mean reduction $=$ $-9.7 \% ; \mathrm{p}<0.001)$ and cycle nutrients $(-7.5 \% ; \mathrm{p}<0.001)$ functions decreased as a result of excess woody debris accumulation following flooding and those conditions persisted during both post-flood sample intervals (post-flood1 vs postflood2; $p>0.520)$. Changes in litter cover decreased the detain precipitation function $(-17.3 \% ; \mathrm{p}<0.001)$, followed by recovery to pre-flood conditions one year after initial data collection (pre-flood vs post-flood $2 \mathrm{p}=0.314$ ). Changes in woody debris and litter compounded to reduce the export organic carbon function $(-23.8 \%$; $<<0.001)$ immediately after the flood, with partial recovery during the post-flood 2 sample interval $(\mathrm{p}<0.001)$. The plant communities and fish and wildlife functions were not altered as a result of the flood (data not shown).

\section{Discussion}

Wetlands within the active Mississippi River floodplain have undergone substantial alteration as a result of levee construction and other disturbances, yet continue to provide high levels of wetland function (DuBowy 2013). The changes in a subset of wetland assessment variables (i.e., alteration of woody debris and litter distribution) is not unexpected, given the hydrodynamics of the constrained floodplain at flood stage. Flood stage discharges and flow velocities were not available at each study locations, but in-channel discharges $>4800 \mathrm{~m}^{3} \mathrm{~s}^{-1}$ were documented at the upstream New Madrid, MO gauge near the sample locations, providing some insight into the energy associated with the flood. Downstream, out-of-channel measurements available for Vicksburg, MS report floodplain discharges exceeding $1.2 \mathrm{~m}^{3} \mathrm{~s}^{-1}$ during the flood. These discharges are sufficient to introduce woody debris into floodplain wetlands and scour/bury litter on the forest floor, inducing the observed changes in wetland assessment variables. Other studies investigate the implications of woody debris and litter content alteration on floodplain ecological processes and functions (Wohl 2020). For example, burial or rafting of leaf litter during flooding alters organic material processing and nutrient cycling within floodplains and rivers (Mayack et al. 1989). The recruitment of woody debris changes sediment capture and floodplain flow velocities (Gurnell et al. 2002). Excessive woody debris transport in floodplains damages vegetation, and prolonged inundation periods may increase tree mortality, providing additional autochthonous sources of snags and woody debris following large flood events (Sparks et al. 1998; Johnson et al. 2000).

Our results contribute to the existing literature by examining short term $(<1$ year) wetland functional responses to a prolonged flood event. The HGM functional assessment applied here proved valuable for identifying flood effects and documenting initial post-flood functional responses following floodwater recession. The HGM assessment approach has previously evaluated impact-response relationships. For example, Berkowitz and White (2013) categorized HGM variables as 1) rapid response variables (e.g., ground vegetation cover), 2) response variables requiring additional time to display a measureable effect (e.g., tree basal area), and 3) stable variables that remain fixed over time (e.g., tract size) in a wetland restoration context. The current study supports this concept with the majority of assessment variables displaying no immediate change following the flood, including all stable offsite variables and response variables associated with mid- to 
Table 2 Summary of HGM assessment variables, description, and sampling technique applied in the study (adapted from Murray and Klimas 2013)

\begin{tabular}{|c|c|c|}
\hline Wetland assessment variable & Description & Sampling technique (units) \\
\hline 1. Wetland tract $\left(\mathrm{V}_{\mathrm{TRACT}}\right)$ & Size of contiguous wetland area & Measured using GIS (ha) \\
\hline 2. Core area $\left(\mathrm{V}_{\mathrm{CORE}}\right)$ & Portion of wetland within $100 \mathrm{~m}$ buffer & Measured using GIS (ha) \\
\hline 3. Habitat connectivity $\left(\mathrm{V}_{\mathrm{CONNECT}}\right)$ & $\begin{array}{l}\text { Proportion of the wetland perimeter connected to } \\
\text { suitable forested habitat }\end{array}$ & Measured using GIS (\%) \\
\hline 4. Flood frequency $\left(\mathrm{V}_{\mathrm{FREQ}}\right)$ & $\begin{array}{l}\text { Change in wetland flood frequency due to recent } \\
\text { activity }\end{array}$ & $\begin{array}{l}\text { Measured using flood frequency map/stream gauge } \\
\text { data (ordinal) }\end{array}$ \\
\hline 5. Flood duration $\left(\mathrm{V}_{\text {DUR }}\right)$ & $\begin{array}{l}\text { Change in wetland flood duration due to recent } \\
\text { activity }\end{array}$ & $\begin{array}{l}\text { Measured using flood duration map/stream gauge } \\
\text { data (ordinal) }\end{array}$ \\
\hline 6. Soil integrity $\left(\mathrm{V}_{\text {SOIL }}\right)$ & $\begin{array}{l}\text { Proportion of the wetland exhibiting altered soils } \\
\text { from recent activity }\end{array}$ & $\begin{array}{l}\text { Onsite and GIS assessment of soil disturbance, } \\
\text { excavation, fill (\%) }\end{array}$ \\
\hline 7. Micro-depressional ponding $\left(\mathrm{V}_{\mathrm{POND}}\right)$ & $\begin{array}{l}\text { Areas exhibiting small topographic depressions and } \\
\text { vernal pool features }\end{array}$ & Visual estimate of areas capable of ponding water $(\%)$ \\
\hline 8. Tree basal area $\left(\mathrm{V}_{\mathrm{TBA}}\right)$ & Basal area per hectare; proportional to tree biomass & Trees identified using a 10 factor prism (count) \\
\hline 9. Litter Cover $\left(\mathrm{V}_{\text {LITTER }}\right)$ & Abundance of leaf litter (i.e., detritus) & Visual estimate of litter cover $(\%)$ \\
\hline 10. Strata Present $\left(V_{\text {STRATA }}\right)$ & Number and type of vegetation layers present & $\begin{array}{l}\text { Presence of trees, shrubs, saplings, and herbaceous } \\
\text { vegetation (count) }\end{array}$ \\
\hline 11. Tree composition $\left(\mathrm{V}_{\mathrm{COMP}}\right)$ & Species composition of the tallest stratum & $\begin{array}{l}\text { Floristic quality of dominant species (USACE 2010) } \\
\text { (weighted average) }\end{array}$ \\
\hline $\begin{array}{l}\text { 12. Downed woody debris biomass and } \\
\text { snags }\left(\mathrm{V}_{\text {DWD\&S }}\right)\end{array}$ & Abundance of woody debris and snag biomass & $\begin{array}{l}\text { Visual assessment of woody debris cover and snags } \\
\text { (ordinal) }\end{array}$ \\
\hline 13. Tree Size Classes $\left(\mathrm{V}_{\text {TREESIZE }}\right)$ & Number of tree size classes present & $\begin{array}{l}\text { Visual inspection for presence of each size class with } \\
\geq 10 \% \text { cover (count) }\end{array}$ \\
\hline
\end{tabular}

long term forested floodplain evolution (e.g., development of forest strata). Additional studies will be required to determine if other variables, including tree basal area and composition will exhibit flood effects at time intervals $>1$ year. In particular, the 2019 event may result in wetland functional shifts because flood inundation persisting into the growing season has been shown to induce tree mortality which in turn impacts micro-depressional ponding (due to uprooting of flood damaged trees) and other factors. For example, Cosgriff et al. (1999) reported tree mortality rates $>40 \%$ and associated shifts in community composition and structure following 195 days of floodplain inundation associated with the 1993 flood on the upper Mississippi River.

The HGM functional assessment has also previously provided insight into recovery trajectories following ecological perturbations (Berkowitz 2018). Here, the rapid recruitment of litter resulted in full recovery of wetland function associated with detention of precipitation and partial recovery of organic carbon export. This response can be attributed to several factors. Floodwaters receded during the height of the growing season (August), a time of rapid herbaceous growth in the lower Mississippi River valley. Recruitment of propagules and hydrochory during flooding likely provided seed sources for rapid vegetation re-establishment (Moore et al. 2011). Also, immediately after the flood many areas exhibited bare ground allowing for herbaceous colonization with minimal competition for space and light. These conditions, in combination with the dominance of deciduous species shedding leaves into the floodplain during the subsequent sample interval (post-flood2) supported litter recuperation following the flood.

The excess woody biomass currently accumulated in the floodplain remains entrapped in debris piles at the base of trees and tangled in drift deposits. The abundance of woody materials will decrease over time, but the degradation, burial, or transport of woody materials in the floodplain will require longer than leaf litter cover to recover. This will delay the return of wetland functions associated with floodwater detention, nutrient cycling, and (to a lesser extent) organic carbon export to pre-flood conditions. Notably, the wetlands examined continued to yield high levels of function after the flood event. This in combination with the mechanisms for ecological recovery described herein highlight the functional resiliency of the forested wetlands within the active Mississippi River floodplain.

The flood did not result in changes to the habitat functions evaluating plant communities, fish, and wildlife. The maintain plant community function does not contain the $\mathrm{V}_{\mathrm{DWD} \& \mathrm{~S}}$ or $\mathrm{V}_{\text {LITTER }}$ variables, precluding changes in that function based upon the results observed following the 2019 flood. The fish and wildlife habitat function incorporates the $\mathrm{V}_{\text {DWD\&S }}$ variable, but the function also considers nine other assessment variables, limiting the influence of $\mathrm{V}_{\mathrm{DWD}}$ \&S on the functional score. Sensitivity analysis indicates that $\mathrm{V}_{\text {DWD\&S }}$ can induce a 
Table 3 Wetland functions assessed at each site using the HGM approach (Murray and Klimas 2013)

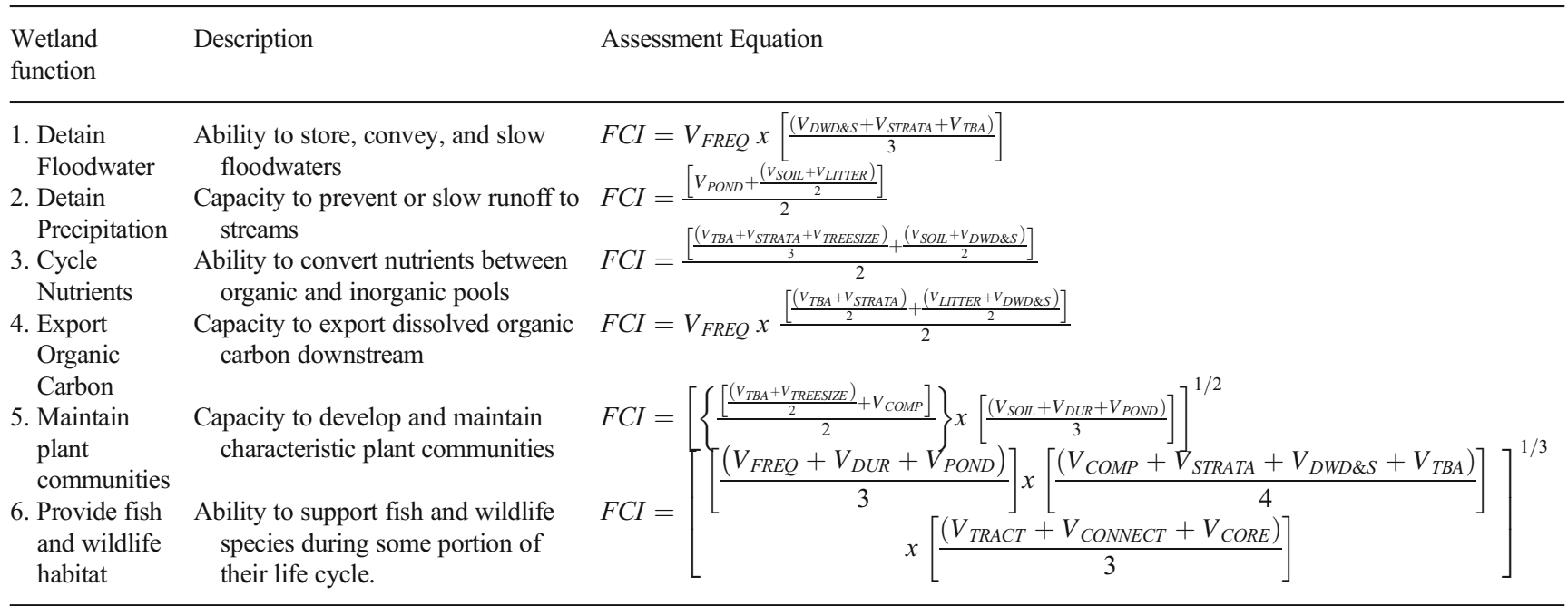

maximum functional capacity index shift of \pm 0.09 . The lack of shifts in habitat functions as a result of the 2019 flood is notable, as numerous studies establish linkages between woody debris, litter, and habitat (Mac Nally et al. 2001;
Schneider and Winemiller 2008). The HGM assessment focuses on quantifying wetland functional capacity and the lack of changes in the habitat functions as a result of flooding does not imply that the methodology lacks responsiveness. Instead,
Fig. 2 Flooding had no impact on most of the assessment variable subindex scores including (a) tree basal area $\left(\mathrm{V}_{\mathrm{TBA}}\right)$ and (b) microdepressional ponding $\left(\mathrm{V}_{\mathrm{POND}}\right)$. However, changes were identified in the (c) downed woody debris and snags $\left(\mathrm{V}_{\mathrm{DWD} \& \mathrm{~S}}\right)$ and $(\mathbf{d})$ litter cover $\left(\mathrm{V}_{\text {LITTER }}\right)$ subindex scores. Error bars represent one standard error and lower case letters indicate where differences were detected between sample intervals
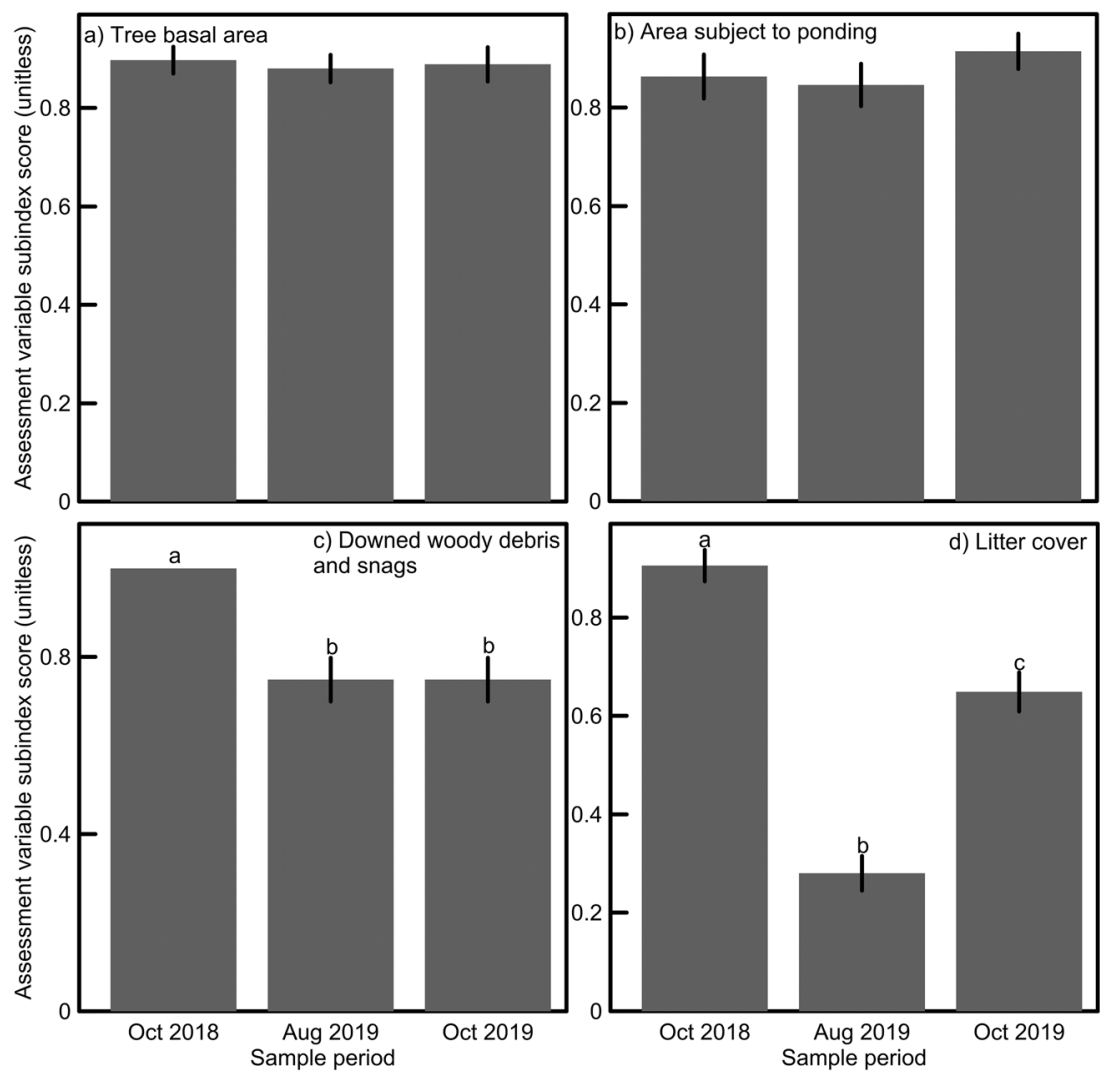
Fig. 3 Flooding decreased the (a) detain floodwater and (b) precipitation, (c) cycle nutrients, and (d) export organic carbon wetland functional capacities. Note that the detain precipitation and export organic carbon functions displayed full and partial recovery, respectively, during subsequent sample intervals. Error bars represent one standard error and lower case letters indicate where differences were detected between sample intervals
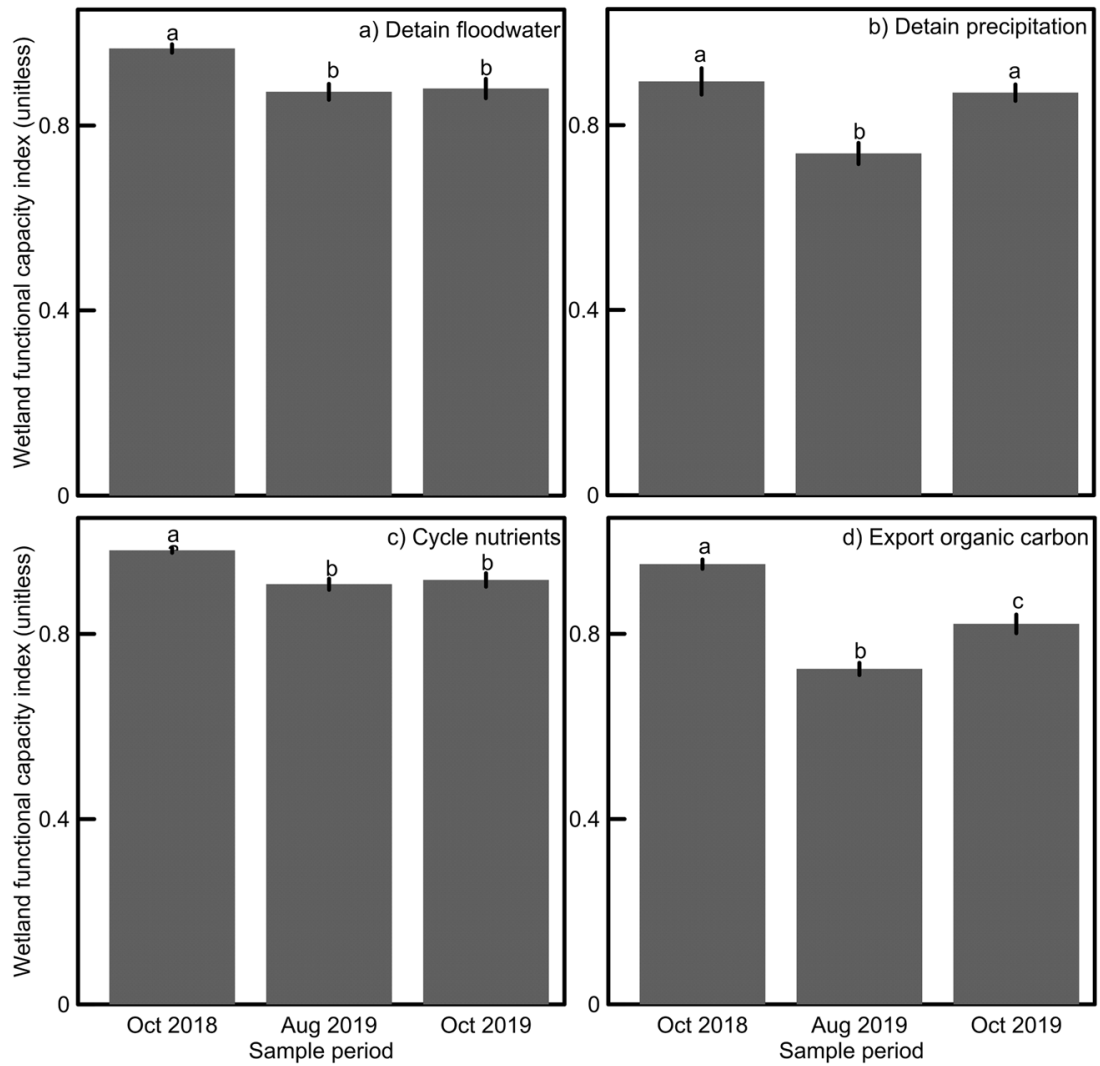

these findings suggest that the flood did not decrease the floodplain wetlands ability to provide plant, fish, and wildlife habitat within the time period examined.

In summary, the 2019 flood provided a unique opportunity to evaluate short term flood effects on wetland functions within the active floodplain of the Mississippi River. Flooding resulted in declines in several wetland functions, with subsequent full or partial recovery in a subset of metrics. Despite the observed shifts, forested wetlands exhibited high levels of wetland functions at all sample intervals and proved resilient to the long duration flood. These findings, in conjunction with other studies, support the application of the HGM assessment approach to evaluate the effects of environmental gradients, impacts, and recovery trajectories at a variety of time scales. Further studies of long term functional responses will provide additional insight into the impact of extended flood events, inform restoration efforts, and improve the management of wetlands within the active floodplains of large rivers.

Acknowledgements Funding for this research was provided by the US Army Corps of Engineers Vicksburg and Memphis Districts and the Mississippi Valley Division. Special thanks to landowners and other entries that coordinated and/or granted site access. Mr. Darrell Evans and Ms. Sydney Bufkin assisted with field data collection and reviewed a draft version of the manuscript.

Open Access This article is licensed under a Creative Commons Attribution 4.0 International License, which permits use, sharing, adaptation, distribution and reproduction in any medium or format, as long as you give appropriate credit to the original author(s) and the source, provide a link to the Creative Commons licence, and indicate if changes were made. The images or other third party material in this article are included in the article's Creative Commons licence, unless indicated otherwise in a credit line to the material. If material is not included in the article's Creative Commons licence and your intended use is not permitted by statutory regulation or exceeds the permitted use, you will need to obtain permission directly from the copyright holder. To view a copy of this licence, visit http://creativecommons.org/licenses/by/4.0/.

\section{References}

Berkowitz JF (2018) Quantifying functional increases across a large-scale wetland restoration chronosequence. Wetlands 39(3):559-573

Berkowitz JF, White JR (2013) Linking wetland functional rapid assessment models with quantitative hydrological and biogeochemical measurements across restoration chronosequence. Soil Science Society of America Journal. 77:1442-1451

Camillo CA (2012) Divine providence: the 2011 flood in the Mississippi River and tributaries project. Mississippi River Commission, Vicksburg

Cosgriff RJ, Nelson JC, Yin Y (1999) Forest response to high duration and intensity flooding along Pool 26 of the upper Mississippi River. Illinois Natural History Survey.:99-01

De Jager NR, Thomsen M, Yin Y (2012) Threshold effects of flood duration on the vegetation and soils of the Upper Mississippi River floodplain, USA. Forest Ecology and Management 270: 135-146

DuBowy PJ (2013) Mississippi River ecohydrology: past, present and future. Ecohydrology \& Hydrobiology 13(1):73-83 
Gurnell AM, Piégay H, Swanson FJ, Gregory SV (2002) Large wood and fluvial processes. Freshwater Biology 47(4):601-619

Johnson SL, Swanson FJ, Grant GE, Wondzell SM (2000) Riparian forest disturbances by a mountain flood - the influence of floated wood. Hydrological Processes 14(16-17):3031-3050

Jones PD, Strickland BK, Demarais S, McKinley WT, Ernst JR, Klassen JA (2019) Seasonal flooding effects on deer in the Mississippi River Batture. The Journal of Wildlife Management 83(5):1117-1130

Mac Nally R, Parkinson A, Horrocks G, Conole L, Tzaros C (2001) Relationships between terrestrial vertebrate diversity, abundance and availability of coarse woody debris on south-eastern Australian floodplains. Biological Conservation 99(2):191-205

Mayack DT, Thorp JH, Cothran M (1989) Effects of burial and floodplain retention on stream processing of allochthonous litter. Oikos 54: 378-388

Moore JE, Franklin SB, Grubaugh JW (2011) Herbaceous plant community responses to fluctuations in hydrology: using Mississippi River islands as models for plant community assembly1. The Journal of the Torrey Botanical Society. 138(2):177-191

Murray EO, Klimas CV (2013) A regional guidebook for applying the hydrogeomorphic approach to assessing functions of forested wetlands in the Mississippi Alluvial Valley. U.S. Army Engineer Research and Development Center, Vicksburg, MS. ERDC/EL TR-13-14

National Oceanic and Atmospheric Administration (NOAA) (2020) U.S. Billion-Dollar Weather and Climate Disasters National Centers for Environmental Information (NCEI). https://www.ncdc.noaa.gov/ billions/. Accessed 01 Jan 2020

Remo JW, Ryherd J, Ruffner CM, Therrell MD (2018) Temporal and spatial patterns of sedimentation within the batture lands of the middle Mississippi River, USA. Geomorphology 308:129-141

Schneider KN, Winemiller KO (2008) Structural complexity of woody debris patches influences fish and macroinvertebrate species richness in a temperate floodplain-river system. Hydrobiologia 610(1): 235-244
Schramm HL, Cox MS, Tietjen TE, Ezell AW (2009) Nutrient dynamics in the lower Mississippi River floodplain: comparing present and historic hydrologic conditions. Wetlands 29(2):476-487

Schramm HL, Richardson WB, Knights BC (2015) Managing the Mississippi River floodplain: achieving ecological benefits requires more than hydrological connection to the river. In: Geomorphic approaches to integrated floodplain management of lowland fluvial systems in North America and Europe. Springer, New York

Smith RD, Klimas CV (2002) A regional guidebook for applying the Hydrogeomorphic approach to assessing wetland functions of selected regional wetland subclasses, Yazoo Basin, lower Mississippi River Alluvial Valley. US Army Engineer Research and Development Center. ERDC/EL TR-02-4

Sparks RE, Nelson JC, Yin Y (1998) Naturalization of the flood regime in regulated rivers: the case of the upper Mississippi River. BioScience 48(9):706-720

Stanturf JA, Gardiner ES, Hamel PB, Devall MS, Leininger TD, Warren ME (2000) Restoring bottomland hardwood ecosystems in the lower Mississippi Alluvial Valley. Journal of Forestry 98(8):10-16

The Nature Conservancy (1992) Restoration of the Mississippi River Alluvial Plain as a functional ecosystem. Baton Rouge, LA

Turner RE, Forsythe SW, Craig NJ (1981) Bottomland hardwood forest land resources of the southeastern United States. Wetlands of bottomland hardwood forests. 11:13-28

U.S. Army Corps of Engineers (2010) Regional supplement to the corps of engineers Wetland delineation manual: Atlantic and Gulf coastal plain region (version 2.0). In Wakeley JS, Lichvar RW, Noble CV (eds) U.S. Army Engineer Research and Development Center, Vicksburg, MS. ERD C/EL TR-10-20

Wohl E (2020) Rivers in the landscape. John Wiley and Sons, Ltd, West Sussex, UK

Publisher's Note Springer Nature remains neutral with regard to jurisdictional claims in published maps and institutional affiliations. 